\title{
Effects of supplementing a Saccharomyces cerevisiae fermentation product during the transition period on rumen fermentation of dairy cows fed fresh diets differing in starch content
}

\author{
W. Shi, ${ }^{1}$ C. E. Knoblock, ${ }^{1}$ I. Yoon, ${ }^{2}$ and M. Oba ${ }^{1 *}$ \\ ${ }^{1}$ Department of Agricultural, Food and Nutritional Science, University of Alberta, Edmonton, AB, Canada T6G 2P5 \\ 2Diamond V, Cedar Rapids, IA 52404
}

\section{ABSTRACT}

The objective of this study was to evaluate the effects of supplementing a Saccharomyces cerevisiae fermentation product (SCFP; NutriTek, Diamond V, Cedar Rapids, IA) during the transition period ( $\mathrm{d}-28 \pm 3$ to $23 \pm 3$ relative to calving) on rumen fermentation and mRNA abundance of genes in the rumen epithelium of fresh cows (d 1 to $23 \pm 3$ after calving) fed diets differing in starch content. Eighteen ruminally cannulated multiparous Holstein cows were fed diets with SCFP $(\mathrm{n}=9)$ or without $(\mathrm{CON} ; \mathrm{n}=9)$ throughout the experiment. All cows were fed a common basal controlled-energy close-up diet $(1.43 \mathrm{Mcal} / \mathrm{kg}$, net energy for lactation; $13.8 \%$ starch) before calving. Cows within each treatment (CON or SCFP) were fed either a low-starch (LS; $22.1 \%$ starch) or high-starch (HS; $28.3 \%$ starch) diet during the fresh period. Cows were assigned to treatment after balancing for parity, body condition score, and expected calving date. Rumen $\mathrm{pH}$ was measured continuously for $72 \mathrm{~h}$ starting on $\mathrm{d}-10,-3,1,7$, and 21 relative to calving date. Rumen papillae were collected on $\mathrm{d}-10$ and 21 relative to calving. Supplementation of SCFP had no effect on rumen $\mathrm{pH}$ during $\mathrm{d}-10$ to -8 , but mean rumen $\mathrm{pH}$ tended to be higher (6.64 vs. 6.49) for SCFP cows than for CON cows during $\mathrm{d}-3$ to -1 . Feeding SCFP decreased the range of rumen $\mathrm{pH}$ variation compared with CON within the HS group during both $\mathrm{d} 7$ to 9 (1.08 vs. 1.38$)$ and $d 21$ to 23 (1.03 vs. 1.30$)$ after calving. In addition, nadir rumen $\mathrm{pH}$ tended to be higher (5.64 vs. 5.44) and duration of $\mathrm{pH}$ below 5.8 tended to be shorter (116 vs. $323 \mathrm{~min} / \mathrm{d}$ ) for the SCFP group than for the CON group during d 21 to 23 after calving. Supplementation of SCFP increased the mRNA abundance of insulin-like growth factor-6 (1.10 vs. 0.69$)$

Received March 23, 2019.

Accepted July 2, 2019

*Corresponding author: moba@ualberta.ca before calving and decreased the mRNA abundance of putative anion transporter isoform 1 (1.12 vs. 2.27) after calving. Nadir rumen $\mathrm{pH}$ tended to be higher during $\mathrm{d} 1$ to 3 (5.63 vs. 5.41) for LS cows than for HS cows, but rumen $\mathrm{pH}$ was not affected by dietary starch content during other time periods. Dietary starch content had no effect on mRNA abundance of genes in the rumen epithelium after calving. These results suggest that supplementation of SCFP may reduce the range of variation in rumen $\mathrm{pH}$ in fresh cows fed HS diets and the duration of subacute ruminal acidosis by the end of the fresh period regardless of dietary starch content and that decreasing dietary starch content during the fresh period may reduce the decrease in rumen $\mathrm{pH}$ immediately after parturition.

Key words: calving transition, dietary starch, Saccharomyces cerevisiae fermentation product, rumen fermentation

\section{INTRODUCTION}

Dairy cows often experience negative energy balance in early lactation because the energy intake lags behind the sudden increase in nutrient demands for milk production (Esposito et al., 2014). High-starch diets are usually fed to early-lactation dairy cows to reduce the energy deficit. However, the large increase in dietary fermentable carbohydrates during the first several weeks after calving decreases rumen $\mathrm{pH}$ and further increases the risk of SARA (Penner et al., 2007). The occurrence of SARA is associated with variable DMI, production losses, and impaired animal health (Stone, 2004; Krause and Oetzel, 2006) and thus may exacerbate the negative energy balance. Therefore, reducing the duration and severity of SARA without compromising energy intake should be taken into account for the nutritional management of transition dairy cows. Reducing dietary starch content by replacing grain with nonforage fiber sources has shown positive effects on rumen fermentation of dairy cows without impairing production performance, such as a tendency for 
higher rumen $\mathrm{pH}$ (Zhang et al., 2010) and lower $\mathrm{pH}$ range (Voelker and Allen, 2003). However, these studies were conducted using dairy cows after peak lactation. A recent study reported that decreasing dietary starch content during the early postpartum period prevented reductions in DMI of cows fed a highly fermentable starch source, but rumen $\mathrm{pH}$ was not measured (Albornoz and Allen, 2018).

Saccharomyces cerevisiae fermentation products (SCFP) have been widely used in dairy cow rations to increase production performance and stabilize the rumen environment (Erasmus et al., 2005). The beneficial effects of SCFP on rumen fermentation include probable stimulation of growth of cellulolytic (Harrison et al., 1988; Zhu et al., 2017) and lactate-utilizing bacteria (Callaway and Martin, 1997), fungi (Mao et al., 2013; Zhu et al., 2017), and protozoa (Arakaki et al., 2000; Shen et al., 2018). Thus, SCFP may contribute to greater fiber digestion, reduced lactate concentration of rumen fluid, and increased microbial protein synthesis (Hristov et al., 2010). In addition, the supplementation of SCFP to beef heifers fed a high-grain diet (52.8\% starch) increased the nadir ruminal $\mathrm{pH}$ and reduced the duration of $\mathrm{pH}<5.6$ by $6 \mathrm{~h}$ compared with control heifers and increased ruminal and total-tract NDF digestibility (Shen et al., 2018). Supplementation of SCFP can reduce the decrease in rumen $\mathrm{pH}$ induced by feeding a high-starch diet (>50\%). However, the interaction effects of dietary starch content and SCFP supplementation on rumen fermentation have not been extensively studied, particularly for the immediate postpartum period.

Therefore, the objective of the current study was to evaluate the effects of SCFP supplementation during the periparturient period on rumen $\mathrm{pH}$, VFA profile, and the mRNA abundance of genes associated with rumen epithelial growth, VFA transporters, and VFA metabolism in the rumen epithelium in fresh cows fed diets differing in starch content. We hypothesized that feeding low-starch diets during the fresh period and supplementing SCFP during the periparturient period would reduce the decrease in rumen $\mathrm{pH}$ after calving and that the benefits of SCFP supplementation would be greater for dairy cows fed high-starch diets.

\section{MATERIALS AND METHODS}

All experimental procedures used in this study were approved by the University of Alberta Animal Care and Use Committee: Livestock (AUP\#1915) and conducted according to the guidelines of the Canadian Council on Animal Care (2009). Two companion papers reported the effects of starch content and SCFP on production performance (Shi et al., 2019) and immune function (Knoblock et al., 2019).

\section{Animals, Diets, and Experimental Design}

Eighteen multiparous, ruminally cannulated Holstein cows, as a subset of 117 dairy cows used in the companion paper (Shi et al., 2019), were blocked by expected calving date and assigned to treatment with efforts to achieve similar pretrial BCS and BW among treatments. These 18 cows were also used in the companion study by Knoblock et al. (2019), where animal information at enrollment can be found. Complete details of the experimental design and animal management are described in Shi et al. (2019). Animal enrollment and data and sample collection were conducted on certain days of the week (e.g., Tuesday) to facilitate routine management of the dairy operation. This protocol allowed deviations of up to $3 \mathrm{~d}$ from the target dates $( \pm 3)$ except for data and sample collection on $d-3$ to 3 relative to calving. Briefly, cows were enrolled in the study at $28 \mathrm{~d}$ before expected calving date and fed diets supplemented with SCFP (NutriTek, Diamond V, Cedar Rapids, IA; $\mathrm{n}=9$ ) or without SCFP $(\mathbf{C O N} ; \mathrm{n}=9)$ until d 23 after calving. The SCFP was a dried culture product produced through anaerobic fermentation of Saccharomyces cerevisiae strains with cereal grain and selected liquids (e.g., molasses) as raw ingredients (Shen et al., 2018). The SCFP was supplemented at 0.173 and $0.095 \%$ of dietary DM in pre- and postpartum diets, respectively, to meet the target inclusion rate of $19 \mathrm{~g} /$ cow per day (as-fed basis) based on expected DMI of the cows (prepartum, $11 \mathrm{~kg} /$ cow per day; postpartum, $20 \mathrm{~kg} /$ cow per day on a DM basis). All cows were fed a common basal controlled-energy diet before calving, containing $13.8 \%$ starch and $1.43 \mathrm{Mcal} / \mathrm{kg}$ of DM. Cows within each treatment (CON or SCFP) were fed either a low-starch (LS; 22.1\%) or high-starch (HS; $28.3 \%$ ) diet from d 1 to 23 after calving, resulting in 4 treatment combinations: LS-CON $(\mathrm{n}=4)$, LS-SCFP (n $=5)$, HS-CON $(\mathrm{n}=5)$, ad HS-SCFP $(\mathrm{n}=4)$. Diet ingredients and nutrient composition are shown in Table 1. Details of feed sampling and analysis are reported in Shi et al. (2019).

\section{Rumen pH and Rumen Fermentation}

Rumen $\mathrm{pH}$ data were recorded every $30 \mathrm{~s}$ continuously for $72 \mathrm{~h}$ (starting with feeding at $0730 \mathrm{~h}$ ) in the ventral sac of the rumen during 5 periods, including $\mathrm{d}$ -10 to -8 relative to expected calving date and $d-3$ to $-1,1$ to 3,7 to 9 , and 21 to 23 relative to actual calving date, using the $\mathrm{pH}$ measurement system developed by 
Table 1. Ingredient and chemical composition of the experimental diets ${ }^{1}$

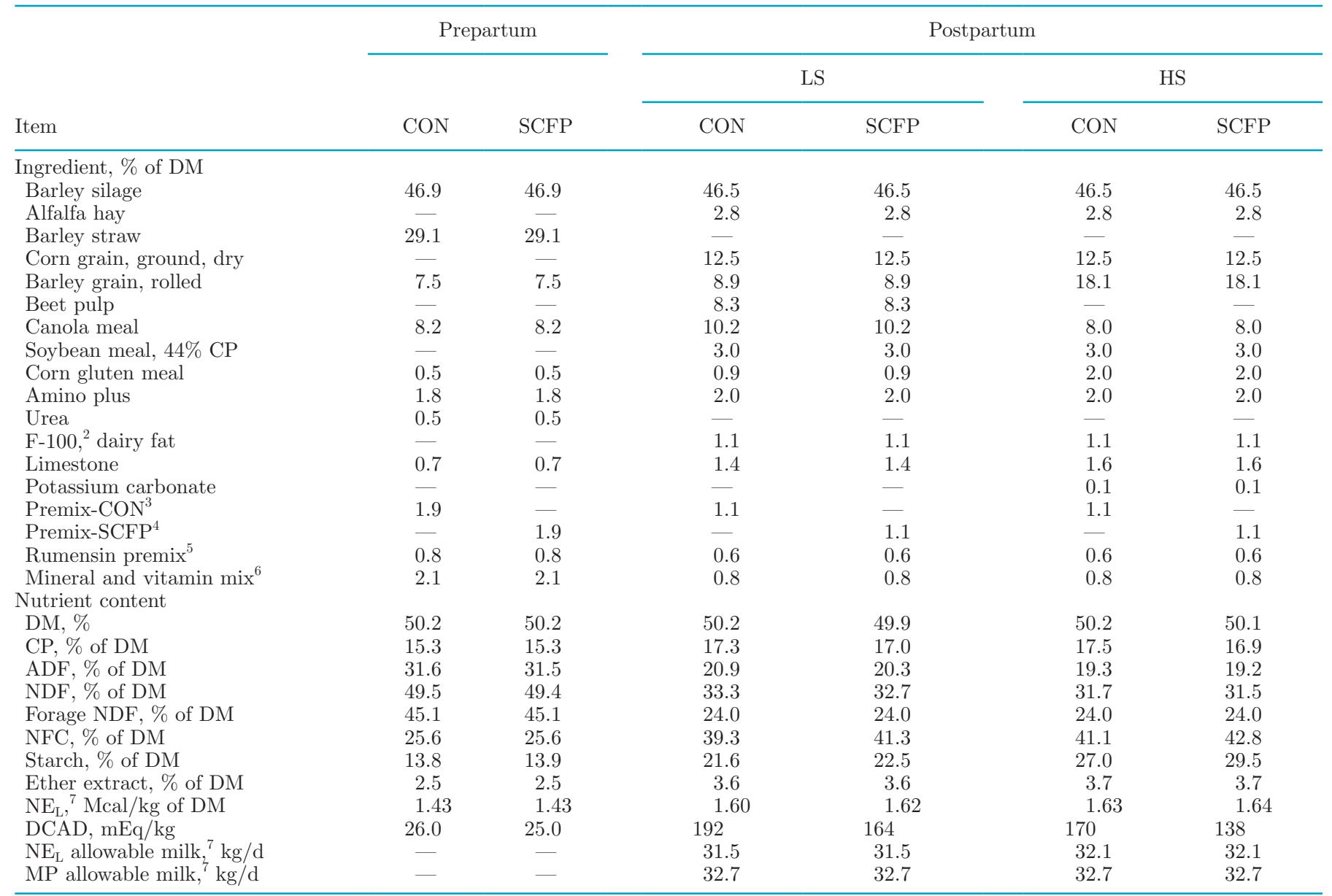

${ }^{1}$ Adapted from Shi et al. (2019). CON = control diet with no Saccharomyces cerevisiae fermentation product (SCFP) supplementation; PremixCON was used in the diet. SCFP = diet supplemented with SCFP; Premix-SCFP was used in the diet. LS = low-starch diets; HS = high-starch diets.

${ }^{2}$ F-100 Dairy Fat (Pro-Ag, Winnipeg, MB, Canada).

${ }^{3}$ Contained $99.0 \%$ dry ground corn grain and $1.0 \%$ canola oil, providing $0 \mathrm{~g}$ of $\mathrm{SCFP} / \mathrm{d}$.

${ }^{4}$ Contained $91.1 \%$ dry ground corn grain, $7.9 \%$ SCFP, and 1.0\% canola oil, providing $19 \mathrm{~g}$ of SCFP/cow per day (as-fed basis) based on expected DMI of cows (11 kg/cow per day before calving; $20 \mathrm{~kg} /$ cow per day after calving).

${ }^{5}$ Contained 1.2\% Rumensin (Elanco Animal Health, Greenfield, IN), 97.5\% dry ground barley grain, and 1.3\% canola oil, providing 1,210 mg of Rumensin/cow per day (as-fed basis) before calving and 1,600 mg of Rumensin/cow per day after calving based on expected DMI (11 kg/cow per day before calving; $20 \mathrm{~kg} / \mathrm{cow}$ per day after calving).

${ }^{6}$ Contained $11.0 \% \mathrm{Ca}, 2.78 \% \mathrm{Na}, 14.2 \% \mathrm{Cl}, 11.8 \% \mathrm{Mg}, 7.68 \% \mathrm{~S}, 16.2 \mathrm{mg} / \mathrm{kg}$ of $\mathrm{Mn}, 4.88 \mathrm{mg} / \mathrm{kg}$ of I, $1,212 \mathrm{kIU} / \mathrm{kg}$ of vitamin A, $121 \mathrm{kIU} / \mathrm{kg}$ of vitamin $\mathrm{D}$, and $4,040 \mathrm{IU} / \mathrm{kg}$ of vitamin $\mathrm{E}$ for close-up diet. Contained $0.71 \% \mathrm{Ca}, 24.3 \% \mathrm{Na}, 39.4 \% \mathrm{Cl}, 13.0 \% \mathrm{Mg}, 0.13 \% \mathrm{~S}, 2,427 \mathrm{mg} / \mathrm{kg}$ of $\mathrm{Cu}$, $4,244 \mathrm{mg} / \mathrm{kg}$ of Mn, $174 \mathrm{mg} / \mathrm{kg}$ of Co, $4,583 \mathrm{mg} / \mathrm{kg}$ of Zn, $10.0 \mathrm{mg} / \mathrm{kg}$ of Se, $85.0 \mathrm{mg} / \mathrm{kg}$ of I, $543 \mathrm{kIU} / \mathrm{kg}$ of vitamin A, $155 \mathrm{kIU} / \mathrm{kg}$ of vitamin $\mathrm{D}$, and $5,118 \mathrm{IU} / \mathrm{kg}$ of vitamin $\mathrm{E}$ for postpartum diets.

${ }^{7}$ Estimated from NRC (2001) using an expected DMI of $20 \mathrm{~kg} / \mathrm{d}$.

Penner et al. (2006). Daily nadir, mean, and maximum rumen $\mathrm{pH}$ and duration and area below rumen $\mathrm{pH} 5.8$ as well as acidosis index (area of $\mathrm{pH}$ below 5.8/DMI) were calculated daily for each cow and averaged for each period. In addition, $\mathrm{pH}$ range was calculated as the difference between nadir and maximum rumen $\mathrm{pH}$ for each cow.
Rumen fluid samples were collected every $9 \mathrm{~h}$ over a 72-h period on d -10 to $-8,7$ to 9 , and 21 to 23 relative to calving. Briefly, samples were collected from cranial dorsal, cranial ventral, central, caudal dorsal, and caudal ventral sacs and then combined and strained through a perforated material (Peetex, pore size $=355$ $\mu \mathrm{m}$; Sefar Canada Inc., Scarborough, ON, Canada). 
Samples were centrifuged at $4^{\circ} \mathrm{C}$ at $3,000 \times g$ for 20 min immediately after collection and stored at $-20^{\circ} \mathrm{C}$ until analysis. Eight rumen fluid samples taken from each period were composited by equal volume to form 1 representative sample for each cow. Gas chromatography was used to determine rumen fluid VFA profile as described by Khorasani et al. (1996).

\section{Rumen Papillae Collection}

Detailed procedures of rumen papillae collection were reported in Knoblock et al. (2019). Briefly, approximately 20 to 30 pieces of rumen papillae were biopsied from the ventral sac of the rumen before morning feeding on $\mathrm{d}-10$ and 21 and were rinsed with ice-cold PBS (pH 7.4) to remove adherent rumen content. After washing, samples were placed into RNAlater (cat. no. AM7020, Thermo Fisher Scientific, Waltham, MA) and stored at $-20^{\circ} \mathrm{C}$ until RNA extraction.

\section{RNA Extraction and Reverse Transcription}

The RNA extraction from rumen papillae samples was conducted according to the method described by Chomczynski and Sacchi (1987). The concentration of RNA was measured at absorbance 260 and 280 $\mathrm{nm}$ using an ND-1000 spectrophotometer (NanoDrop Technologies, Wilmington, DE). The absorbance ratio (260:280) of all the samples was between 1.96 and 2.08, suggesting high RNA purity. Single-strand cDNA was synthesized using the iScript Reverse Transcription Supermix (Bio-Rad, Montreal, QC, Canada). Samples of cDNA were diluted $20 \times$ using nuclease-free water and stored at $-80^{\circ} \mathrm{C}$ until use.

\section{Quantitative Real-Time PCR}

Before quantitative real-time PCR, primers were tested to ensure the presence of desired genes (Table 2 ) in all samples. The quantitative real-time PCR was then conducted to measure the relative expression of genes associated with rumen epithelial growth, VFA absorption, and VFA metabolism using the StepOnePlus Real-Time PCR system (Applied Biosystems, Foster City, CASA) using the Fast SYBR Green kits. The reactions were performed according to the following conditions: $20 \mathrm{~s}$ at $50^{\circ} \mathrm{C}, 40$ cycles of $3 \mathrm{~s}$ at $95^{\circ} \mathrm{C}$ and $30 \mathrm{~s}$ at 60 or $63^{\circ} \mathrm{C}$. All samples were run in triplicate.

Three housekeeping genes were used in this study, including $\beta$-actin $(A C T B)$, glyceraldehyde-3-phosphate dehydrogenase $(G A D P H)$, and ribosomal protein large, P0 (RPLP0). These housekeeping genes were expressed in all samples and not affected by treatment. The rela- tive changes in gene expression were calculated using the $2^{-\Delta \Delta \mathrm{C}}$ T method (Livak and Schmittgen, 2001). One cow in the LS-SCFP group with the lowest mean rumen $\mathrm{pH}$ during the $\mathrm{d}-10$ sampling period was chosen as the calibrator. The $\Delta \mathrm{C}_{\mathrm{T}}$ was calculated as the difference between the cycle threshold $\left(\mathbf{C}_{\mathbf{T}}\right)$ for each cow and gene and the corresponding geometric mean of 3 housekeeping genes. The $\Delta \Delta \mathrm{C}_{\mathrm{T}}$ for each cow and gene was then calculated by subtracting $\Delta \mathrm{C}_{\mathrm{T}}$ of the calibrator from the $\Delta \mathrm{C}_{\mathrm{T}}$.

\section{Statistical Analysis}

Statistical analyses were conducted using the Fit Model procedure of JMP 13 (SAS Institute Inc., Cary, NC). Prepartum and postpartum data were analyzed using models 1 and 2, respectively:

$$
\begin{gathered}
Y_{i}=\mu+T_{i}+e_{i}, \\
Y_{i j}=\mu+T_{i}+S_{j}+T S_{i j}+e_{i j},
\end{gathered}
$$

where $Y_{i}$ or $Y_{i j}=$ observations for dependent variables, $\mu=$ overall mean, $T_{i}=$ fixed effect of SCFP supplementation (CON or SCFP), $S_{j}=$ fixed effects of starch content of fresh diets (LS or HS), $T S_{i j}=$ effect of SCFP and starch content interaction, and $e_{i}$ or $e_{i j}=$ residuals. Comparisons among treatments were conducted using Student's $t$-test when an interaction between SCFP supplementation and starch content was detected. Significance was declared at $P \leq 0.05$ and tendency was declared at $0.05<P \leq 0.10$.

\section{RESULTS}

There were no treatment effects on DMI during periods of rumen $\mathrm{pH}$ measurement (Tables 3, 4, 5, 6, and 7), and DMI data were presented solely to show the components of the acidosis index calculations. Dry matter intake data for a full set of 117 dairy cows are shown in the companion paper (Shi et al., 2019).

\section{Rumen $\mathrm{pH}$ and VFA Profile}

During the $\mathrm{d}-10$ sampling period, no differences were observed in nadir, mean, and maximum rumen $\mathrm{pH}$ between SCFP and CON groups or in duration and area of rumen $\mathrm{pH}$ below 5.8 (Table 3). Total VFA concentration and molar proportions of butyrate and propionate were not different between SCFP and CON groups, but molar proportion of acetate tended to be greater for SCFP cows than for CON cows $(P=0.10)$. During the $\mathrm{d}-3$ sampling period, nadir rumen $\mathrm{pH}$ was 


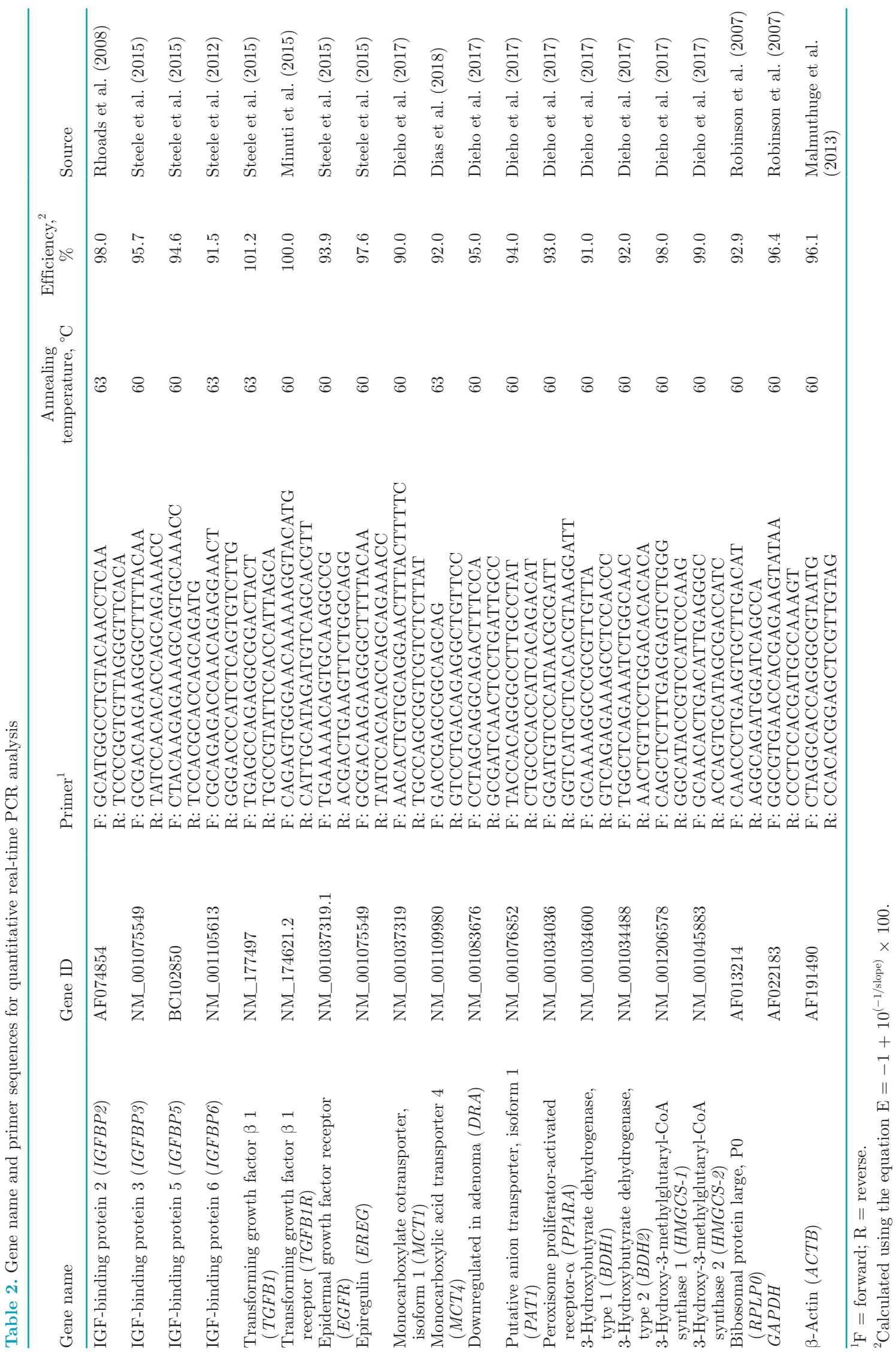


Table 3. Effects of Saccharomyces cerevisiae fermentation product (SCFP) supplementation on rumen fermentation during $\mathrm{d}-10$ to -8 before calving

\begin{tabular}{|c|c|c|c|c|}
\hline \multirow[b]{2}{*}{ Variable } & \multicolumn{2}{|c|}{ Treatment $^{1}$} & \multirow[b]{2}{*}{ SE } & \multirow[b]{2}{*}{$P$-value } \\
\hline & $\mathrm{CON}$ & SCFP & & \\
\hline $\mathrm{DMI}, \mathrm{kg} / \mathrm{d}$ & 12.3 & 11.2 & 0.78 & 0.32 \\
\hline \multicolumn{5}{|l|}{ Rumen $\mathrm{pH}$} \\
\hline Nadir & 5.99 & 6.08 & 0.10 & 0.53 \\
\hline Mean & 6.50 & 6.54 & 0.07 & 0.73 \\
\hline Maximum & 6.95 & 6.99 & 0.04 & 0.55 \\
\hline Range & 0.97 & 0.91 & 0.10 & 0.68 \\
\hline Duration $\mathrm{pH}<5.8, \mathrm{~min} / \mathrm{d}$ & 20.1 & 56.3 & 46.1 & 0.59 \\
\hline Area $\mathrm{pH}<5.8, \mathrm{pH} \times \min / \mathrm{d}$ & 2.79 & 17.8 & 14.6 & 0.48 \\
\hline Acidosis index, $\mathrm{pH} \times \min / \mathrm{kg}$ & 0.27 & 2.78 & 2.29 & 0.45 \\
\hline \multicolumn{5}{|l|}{ Rumen VFA } \\
\hline Total VFA, mM & 136 & 133 & 5.67 & 0.64 \\
\hline Acetate, $\mathrm{mol} / 100 \mathrm{~mol}$ & 64.9 & 66.1 & 0.45 & 0.10 \\
\hline Propionate, $\mathrm{mol} / 100 \mathrm{~mol}$ & 21.7 & 20.6 & 0.76 & 0.33 \\
\hline Butyrate, mol/100 mol & 9.14 & 8.98 & 0.31 & 0.72 \\
\hline Isobutyrate, $\mathrm{mol} / 100 \mathrm{~mol}$ & 1.12 & 1.10 & 0.02 & 0.63 \\
\hline Valerate, $\mathrm{mol} / 100 \mathrm{~mol}$ & 1.24 & 1.26 & 0.07 & 0.85 \\
\hline Isovalerate, $\mathrm{mol} / 100 \mathrm{~mol}$ & 1.48 & 1.53 & 0.16 & 0.81 \\
\hline Caproate, $\mathrm{mol} / 100 \mathrm{~mol}$ & 0.37 & 0.40 & 0.07 & 0.76 \\
\hline Acetate:propionate & 3.02 & 3.22 & 0.12 & 0.24 \\
\hline
\end{tabular}

${ }^{1} \mathrm{CON}=$ control diet with no SCFP supplementation; SCFP = SCFP-supplemented diet.

Table 4. Effects of Saccharomyces cerevisiae fermentation product (SCFP) supplementation on rumen fermentation during $\mathrm{d}-3$ to -1 before calving

\begin{tabular}{lcccc}
\hline & \multicolumn{2}{c}{ Treatment $^{1}$} & & \\
\cline { 2 - 3 } Variable & CON & SCFP & SE & P-value \\
\hline DMI, kg/d & 11.5 & 10.4 & 0.90 & 0.43 \\
Rumen $\mathrm{pH}$ & & & & \\
Nadir & 6.03 & 6.18 & 0.09 & 0.22 \\
Mean & 6.49 & 6.64 & 0.06 & 0.09 \\
Maximum & 6.97 & 7.12 & 0.05 & 0.08 \\
Range & 0.95 & 0.94 & 0.10 & 0.93 \\
Duration $\mathrm{pH}<5.8, \mathrm{~min} / \mathrm{d}$ & 22.1 & 13.3 & 14.0 & 0.67 \\
Area $\mathrm{pH}<5.8, \mathrm{pH} \times \mathrm{min} / \mathrm{d}$ & 2.18 & 4.66 & 3.44 & 0.62 \\
Acidosis index, $\mathrm{pH} \times \mathrm{min} / \mathrm{kg}$ & 0.27 & 0.66 & 0.49 & 0.58 \\
\hline
\end{tabular}

${ }^{1} \mathrm{CON}=$ control diet with no SCFP supplementation; SCFP $=$ SCFP-supplemented diet.

Table 5. Effects of starch content of fresh diets (ST) and supplementation of a Saccharomyces cerevisiae fermentation product (SCFP) on rumen fermentation during $\mathrm{d} 1$ to 3 after calving

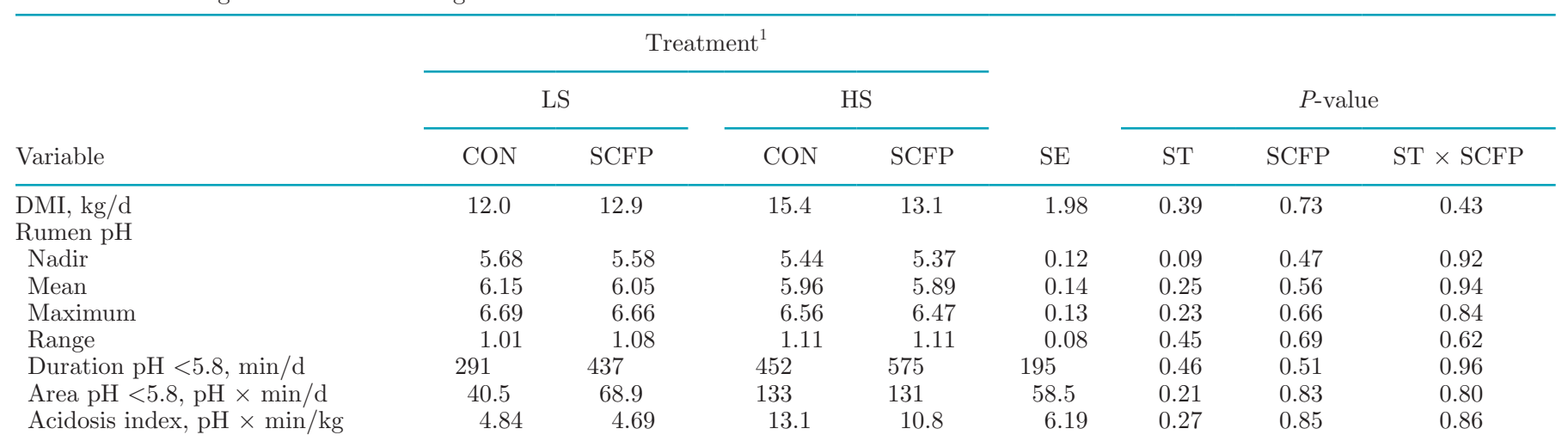

${ }^{1} \mathrm{LS}=$ low-starch fresh diets; HS $=$ high-starch fresh diets; CON $=$ control diet with no SCFP supplementation; SCFP $=$ diet with SCFP supplementation. 
Table 6. Effects of starch content of fresh diets (ST) and supplementation of a Saccharomyces cerevisiae fermentation product (SCFP) on rumen fermentation during d 7 to 9 after calving

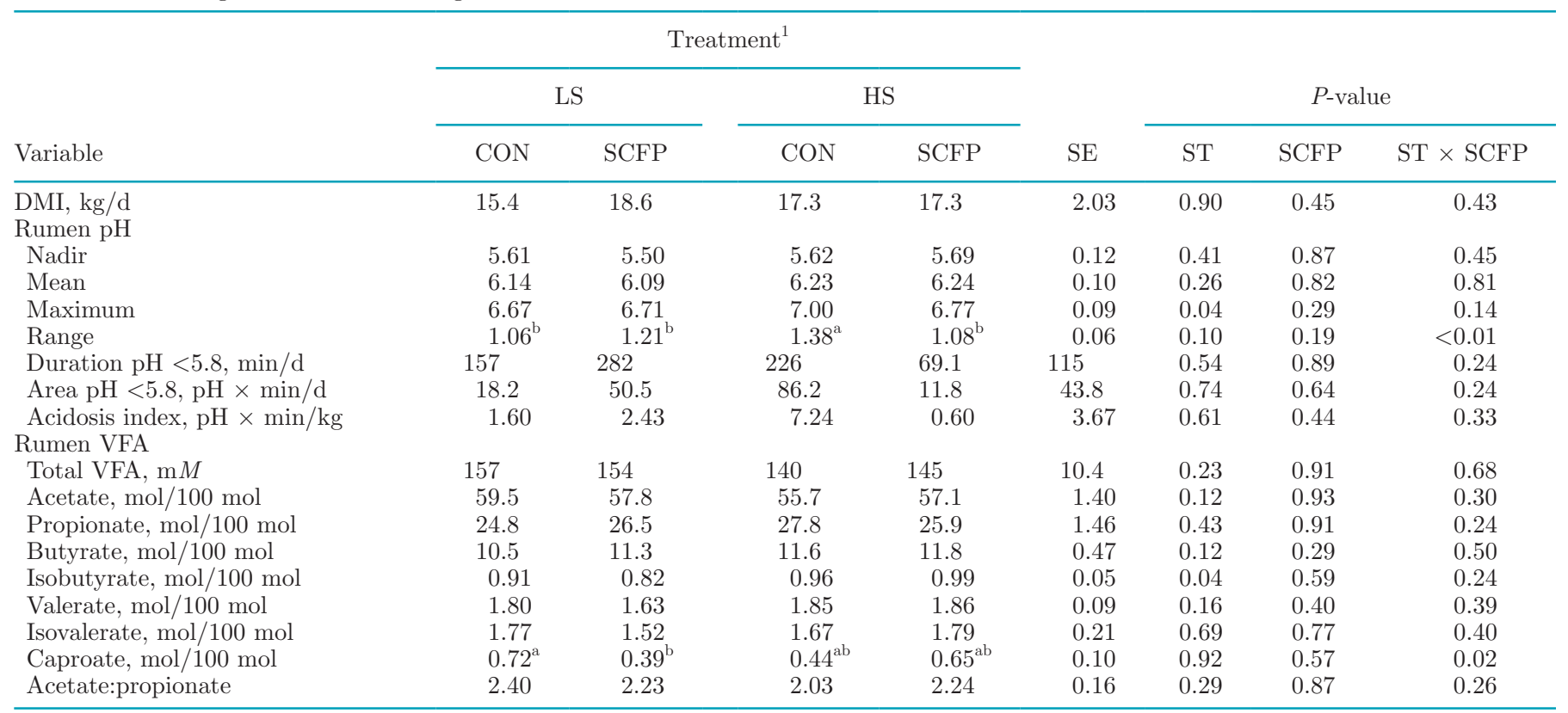

${ }^{\mathrm{a}, \mathrm{b}}$ Means within a row with different superscripts differ significantly $(P<0.05)$ when an interaction of main treatment effect was observed. ${ }^{1} \mathrm{LS}=$ low-starch fresh diets; HS = high-starch fresh diets; CON = control diet with no SCFP supplementation; SCFP $=$ diet with SCFP supplementation.

Table 7. Effects of starch content of fresh diets (ST) and supplementation of a Saccharomyces cerevisiae fermentation product (SCFP) on rumen fermentation during d 21 to $23 \pm 3$ after calving

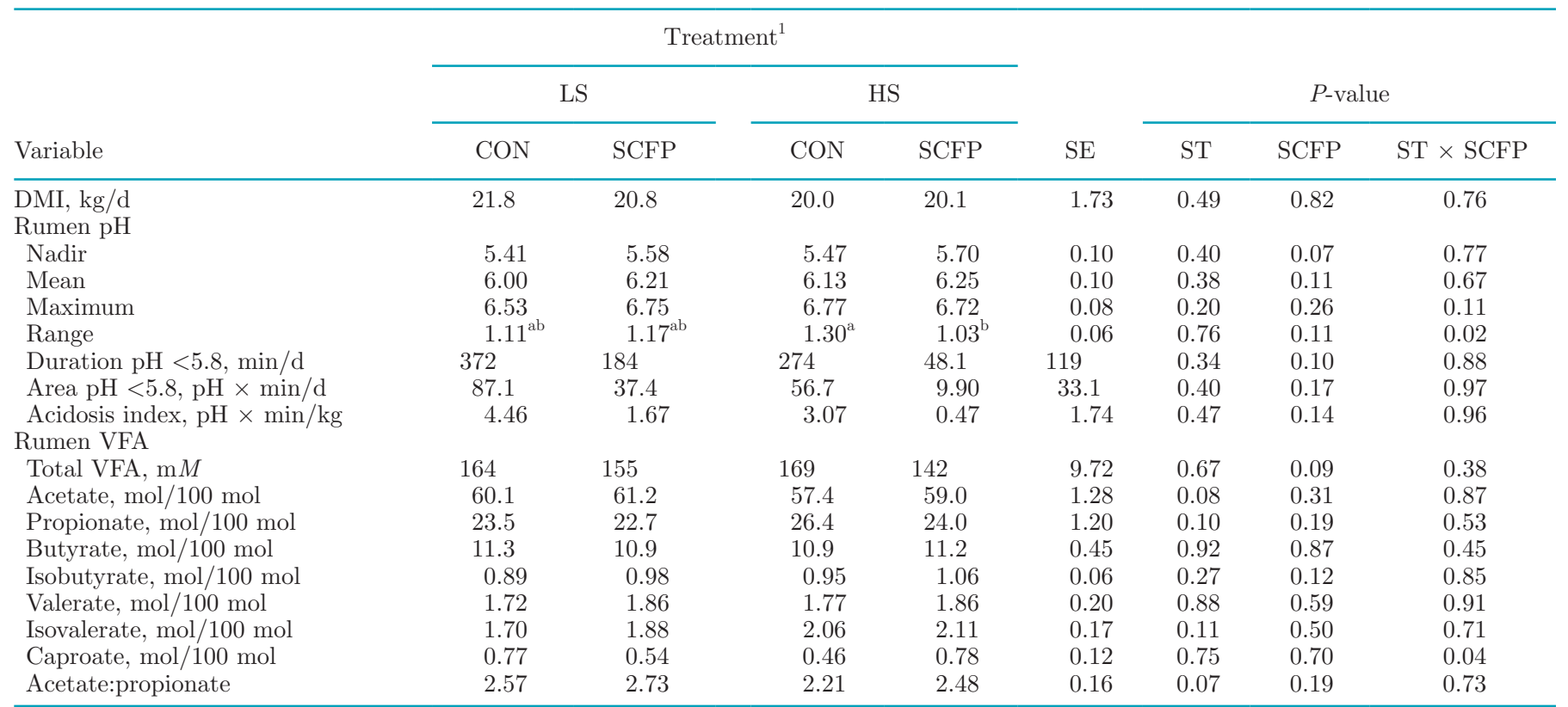

${ }_{\mathrm{a}, \mathrm{b}}$ Means within a row with different superscripts differ significantly $(P<0.05)$ when an interaction of main treatment effect was observed. ${ }^{1} \mathrm{LS}=$ low-starch fresh diets; HS = high-starch fresh diets; CON = control diet with no SCFP supplementation; SCFP $=$ diet with SCFP supplementation. 
not affected by SCFP supplementation, but mean rumen $\mathrm{pH}$ tended to be higher for SCFP cows than for CON cows (Table $4 ; P=0.09$ ). The duration and area of rumen $\mathrm{pH}$ below 5.8 did not differ between the SCFP and CON groups.

After calving, no interactions were observed for SCFP supplementation and dietary starch content for most of the rumen $\mathrm{pH}$ parameters and VFA profile (Tables 5, 6 , and 7), except for rumen $\mathrm{pH}$ range during the $\mathrm{d} 7$ $(P<0.01)$ and $21(P=0.02)$ sampling periods. Within HS group, SCFP supplementation decreased rumen $\mathrm{pH}$ range compared with CON during both the $\mathrm{d} 7$ and $\mathrm{d}$ 21 sampling period. During both the d 1 and d 7 sampling periods, SCFP supplementation had no effects on nadir, mean, and maximum rumen $\mathrm{pH}$ or on duration and area of rumen $\mathrm{pH}$ below 5.8. Total VFA concentration and VFA profiles were not different between SCFP and CON cows during the 7 sampling period. During the $\mathrm{d} 21$ sampling period, nadir rumen $\mathrm{pH}$ tended to be higher (5.64 vs. $5.44 ; P=0.07)$ and duration of $\mathrm{pH}$ below 5.8 tended to be lower (116 vs. $323 \mathrm{~min} / \mathrm{d} ; P$ $=0.10)$ for the cows fed SCFP than the CON cows. However, there were no differences in mean rumen $\mathrm{pH}$ and area of rumen $\mathrm{pH}$ below 5.8 between the SCFP and CON groups. Total VFA concentration tended to be lower (149 vs. $166 \mathrm{mM} ; P=0.09$ ) for the SCFP group than for the CON group, whereas VFA profiles were not affected by SCFP supplementation.

Dietary starch content had no effect on mean rumen $\mathrm{pH}$ and duration and area of rumen $\mathrm{pH}$ below 5.8 during the d 1 sampling period, but nadir ruminal $\mathrm{pH}$ tended to be higher for LS cows than for HS cows (5.63 vs. $5.41 ; P=0.09$ ). During the $\mathrm{d} 7$ sampling period, only maximum rumen $\mathrm{pH}$ was affected by dietary starch content and was lower for LS cows compared with HS cows (6.69 vs. $6.89 ; P=0.04)$. Total VFA and VFA profiles were not affected by dietary starch content. During the d 21 sampling period, none of the rumen $\mathrm{pH}$ parameters were affected by starch content. Total VFA concentration was not different between the LS and HS groups. However, molar proportion of acetate tended to be higher (60.6 vs. $58.2 \mathrm{~mol} / 100 \mathrm{~mol}$; $P=0.08)$ and molar proportion of propionate tended to be lower (23.1 vs. $25.2 \mathrm{~mol} / 100 \mathrm{~mol} ; P=0.10)$ for LS cows compared with the HS cows, resulting in a tendency of higher acetate:propionate ratio (2.65 vs. 2.34; $P=0.07$ ) for the cows fed the LS diet compared with the cows fed the HS diet.

\section{Rumen Epithelium Gene Expression}

Before calving, the relative mRNA abundance of genes encoding for VFA transporters and epithelial cell VFA metabolism were not different between the
SCFP and CON groups (Table 8). In addition, among the genes encoding for rumen epithelium growth, the relative mRNA abundance of transforming growth factor $\beta 1$ (TGFB1) and its receptor (TGFBR1), epidermal growth factor receptor $(E G F R)$, and epiregulin $(E R E G)$ did not differ between SCFP and CON cows. However, among those IGF-binding proteins $(I G F B P)$, the relative mRNA abundance of $I G F B P 6$ was higher for the cows fed SCFP compared with the CON group, whereas the relative mRNA abundance of IGFBP2, $I G F B P 3$, and IGFBP5 was not different between the SCFP and CON groups.

After calving, the interaction effects of SCFP supplementation and dietary starch content were observed only for the expression of 3-hydroxybutyrate dehydrogenase, type 2 (BDH2; Table 9). The majority of the genes evaluated in this study were not affected by SCFP supplementation, but the relative mRNA abundance of putative anion transporter isoform 1 (PAT1) was lower for the SCFP group compared with the CON group (1.12 vs. $2.27 ; P=0.01)$. Dietary starch content had no effect on the expression of the genes evaluated in this study.

\section{DISCUSSION}

\section{Effects of SCFP Supplementation}

In the companion paper (Shi et al., 2019), it was found that supplementation of SCFP transiently increased DMI on d 1 and 5 after calving, whereas overall DMI during both the close-up and fresh periods was not different between the SCFP and CON cows. In addition, SCFP supplementation reduced serum concentrations of haptoglobin on d 7 after calving compared with CON (Knoblock et al., 2019).

In the current study, we found that SCFP supplementation tended to increase molar proportion of acetate during the $\mathrm{d}-10$ sampling period and mean rumen $\mathrm{pH}$ during the $\mathrm{d}-3$ sampling period. These may indicate increased fiber digestion. Previous studies have shown that SCFP supplementation increased the growth and activity of certain fiber-digesting bacteria (Harrison et al., 1988; Callaway and Martin, 1997). More recently, it has been reported that there was a linear increase in the population of certain cellulolytic bacteria in response to an increasing amount of SCFP in mid-lactation dairy cows fed low-quality forage (Zhu et al., 2017).

In addition to the changes in rumen fermentation, increased mRNA abundance of IGFBP 6 was observed for SCFP-supplemented cows. As a member of the IGFBP family, IGFBP 6 binds IGF-2 preferentially over IGF1 and inhibits IGF-2 actions, including proliferation, differentiation, and survival of many cell types (Bach, 
Table 8. Effects of supplementation of a Saccharomyces cerevisiae fermentation product (SCFP) on relative mRNA abundance in rumen papillae on $\mathrm{d}-10 \pm 3$ relative to expected calving date

\begin{tabular}{|c|c|c|c|c|}
\hline \multirow[b]{2}{*}{ Gene $^{1}$} & \multicolumn{2}{|c|}{ Treatment $^{2}$} & \multirow[b]{2}{*}{$\mathrm{SE}$} & \multirow[b]{2}{*}{$P$-value } \\
\hline & $\mathrm{CON}$ & SCFP & & \\
\hline \multicolumn{5}{|c|}{ Rumen epithelial growth and differentiation } \\
\hline$I G F B P 2$ & 1.52 & 3.49 & 0.95 & 0.17 \\
\hline IGFBP3 & 0.47 & 0.62 & 0.13 & 0.46 \\
\hline IGFBP5 & 0.83 & 0.75 & 0.17 & 0.75 \\
\hline IGFBP 6 & 0.69 & 1.10 & 0.09 & 0.01 \\
\hline TGFB1 & 1.02 & 1.12 & 0.11 & 0.55 \\
\hline$T G F B R 1$ & 0.91 & 0.82 & 0.12 & 0.59 \\
\hline EGFR & 1.37 & 1.63 & 0.57 & 0.75 \\
\hline$E R E G$ & 62.9 & 83.0 & 21.7 & 0.53 \\
\hline \multicolumn{5}{|c|}{ VFA transporter } \\
\hline$M C T 1$ & 1.28 & 1.10 & 0.33 & 0.70 \\
\hline $\mathrm{MCT}_{4}$ & 1.99 & 1.77 & 0.30 & 0.62 \\
\hline PAT1 & 1.73 & 1.64 & 0.35 & 0.86 \\
\hline$D R A$ & 0.89 & 1.07 & 0.27 & 0.66 \\
\hline \multicolumn{5}{|c|}{ VFA metabolism } \\
\hline PPARA & 1.34 & 1.39 & 0.34 & 0.91 \\
\hline BDH1 & 1.05 & 0.86 & 1.35 & 0.33 \\
\hline BDH2 & 0.63 & 0.66 & 0.14 & 0.87 \\
\hline HMGCS1 & 0.77 & 1.15 & 0.28 & 0.37 \\
\hline$H M G C S 2$ & 1.60 & 0.83 & 0.33 & 0.12 \\
\hline \multicolumn{5}{|c|}{$\begin{array}{l}{ }_{1} I G F B P 2=\text { IGF-binding protein } 2 ; I G F B P 3=\text { IGF-binding protein } 3 ; I G F B P 5=\text { IGF-binding protein } 5 \\
I G F B P 6=\text { IGF-binding protein } 6 ; T G F B 1=\text { transforming growth factor } \beta 1 ; T G F B R 1=\text { transforming growt } 1 \text { t } \\
\text { factor } \beta \text { receptor } 1 ; E G F R=\text { epidermal growth factor receptor; } E R E G=\text { epiregulin; } M C T 1=\text { monocarboxylat } \\
\text { cotransporter, isoform } 1 ; M C T 4=\text { monocarboxylate cotransporter, isoform } 4 ; P A T 1=\text { putative anion trans } \\
\text { porter, isoform } 1 ; D R A=\text { downregulated in adenoma; } P P A R A=\text { peroxisome proliferator-activated receptor- } \\
B D H 1=\beta-118 \text { hydroxybutyrate dehydrogenase, isoform } 1 ; B D H 2=\beta-118 \text { hydroxybutyrate dehydrogenase } \\
\text { isoform } 2 ; H M G C S 1=3 \text {-hydroxy-3-methylglutaryl-CoA synthase } 1 ; H M G C S 2=3 \text {-hydroxy-3-methylglutaryl } \\
\text { CoA synthase } 2 .\end{array}$} \\
\hline
\end{tabular}

2016). It has been reported that the expression of $I G F B P 6$ was downregulated during high-grain feeding (Steele et al., 2011) and was upregulated with increased NDF:starch ratio (Ma et al., 2017), suggesting that the expression of IGFBP 6 may be related to the dietary NDF content. However, NDF content was similar between the SCFP and CON diets in our study; therefore, the greater mRNA abundance of IGFBP 6 for the SCFP group may be related to the tendency of higher molar proportion of acetate.

In this study, we hypothesized that supplementation of SCFP would reduce the decrease in rumen $\mathrm{pH}$ associated with the sudden change in diet composition after calving, particularly to a greater extent for dairy cows fed a high-starch fresh diet compared with those fed a low-starch fresh diet. Nadir rumen $\mathrm{pH}$ tended to be greater and duration of rumen $\mathrm{pH}$ below 5.8 tended to be shorter for SCFP cows compared with CON cows during the $\mathrm{d} 21$ sampling period, but SCFP supplementation did not affect rumen $\mathrm{pH}$ during the $\mathrm{d} 1$ and $\mathrm{d} 7$ sampling periods; duration of rumen $\mathrm{pH}$ below 5.8 and acidosis index were numerically 3 - and 12 -fold higher for HS-CON cows than for HS-SCFP cows during the d 7 sampling period. The low number of animals per treatment along with substantial inherent variation among cows immediately after calving, as indicated by the large standard error values, may have masked treatment differences.

In addition, the lack of treatment effect in rumen $\mathrm{pH}$ response to SCFP supplementation may be related to the lower SCFP intake relative to the target. The postpartum diets in our study were formulated based on an expected DMI of $20 \mathrm{~kg} / \mathrm{d}$ and to provide SCFP at $19 \mathrm{~g} / \mathrm{d}$ (as fed) according to the manufacturer's recommendation. However, the actual SCFP intakes, calculated from the average DMI during d 1 (13.4 $\mathrm{kg} / \mathrm{d})$ and d $7(17.2 \mathrm{~kg} / \mathrm{d})$, were 12.7 and $16.3 \mathrm{~g} / \mathrm{d}$, respectively. This was 33 and $14 \%$ less than the target amount, respectively; therefore, the unexpected lower SCFP intake during the immediate postpartum period may account for the differences in rumen $\mathrm{pH}$ response to SCFP supplementation during the different sampling periods. In support of this speculation, in our companion study (Shi et al., 2019), the positive effects of SCFP supplementation were greater during the postfresh early-lactation period (d 24-44) than during the fresh period (d 1-23). For example, the increase in feed efficiency was observed for the dairy cows in the SCFP 
group during the post-fresh early-lactation period but not during the fresh period.

However, we observed reduced variation ranges of rumen $\mathrm{pH}$ for SCFP cows compared with CON cows fed HS fresh diets during both the d 7 and 21 sampling periods. These findings indicate that SCFP supplementation can reduce diurnal variation of rumen $\mathrm{pH}$ and stabilize rumen fermentation, particularly under highstarch feeding conditions, probably by maintaining the rumen microbial population (Guo et al., 2018). It was reported that SCFP supplementation prevented the reduction in rumen microbial diversity in dairy cows during grain-induced SARA challenges at wk 5 and 8 after calving (Guo et al., 2018), which help maintain a stable rumen environment. In addition, SCFP supplementation has been reported to facilitate the growth of lactic acid-utilizing bacteria (Callaway and Martin, 1997) and increase the protozoa count in the rumen (Arakaki et al., 2000; Shen et al., 2018), contributing to a more stable rumen environment, particularly for cows fed high-starch diets. Rumen protozoa have been proposed to prevent the decrease in rumen $\mathrm{pH}$ by en- gulfing starch granules and reducing the starch degradation by amylolytic bacteria (Williams and Coleman, 1997), decreasing VFA production rate. Therefore, we speculated that reduced variation ranges in rumen $\mathrm{pH}$ for HS-SCFP cows compared with HS-CON cows may be related to an increase in ruminal protozoa count.

Besides rumen $\mathrm{pH}$, we also observed a tendency of lower total VFA concentration and lower mRNA abundance of PAT1 for the cows in the SCFP group compared with the CON group. The PAT1 is a transporter protein that is involved in the bicarbonate-dependent transport pathway, which transports dissociated VFA into rumen epithelial cells and moves bicarbonate ions back to the ruminal lumen (Connor et al., 2010). It has been reported that incubation of rumen epithelial cells isolated from goats with VFA increased the mRNA expression of PAT1, but decreasing the $\mathrm{pH}$ of the incubation medium had no effect on PAT1 expression (Yan et al., 2014). This suggested that the lower mRNA abundance of PAT1 for the cows fed SCFP may be associated with the tendency for lower total VFA concentration compared with the CON group. In ad-

Table 9. Effects of starch content of fresh diets (ST) and supplementation of a Saccharomyces cerevisiae fermentation product (SCFP) on relative mRNA abundance in rumen papillae on d $21 \pm 3$ after calving

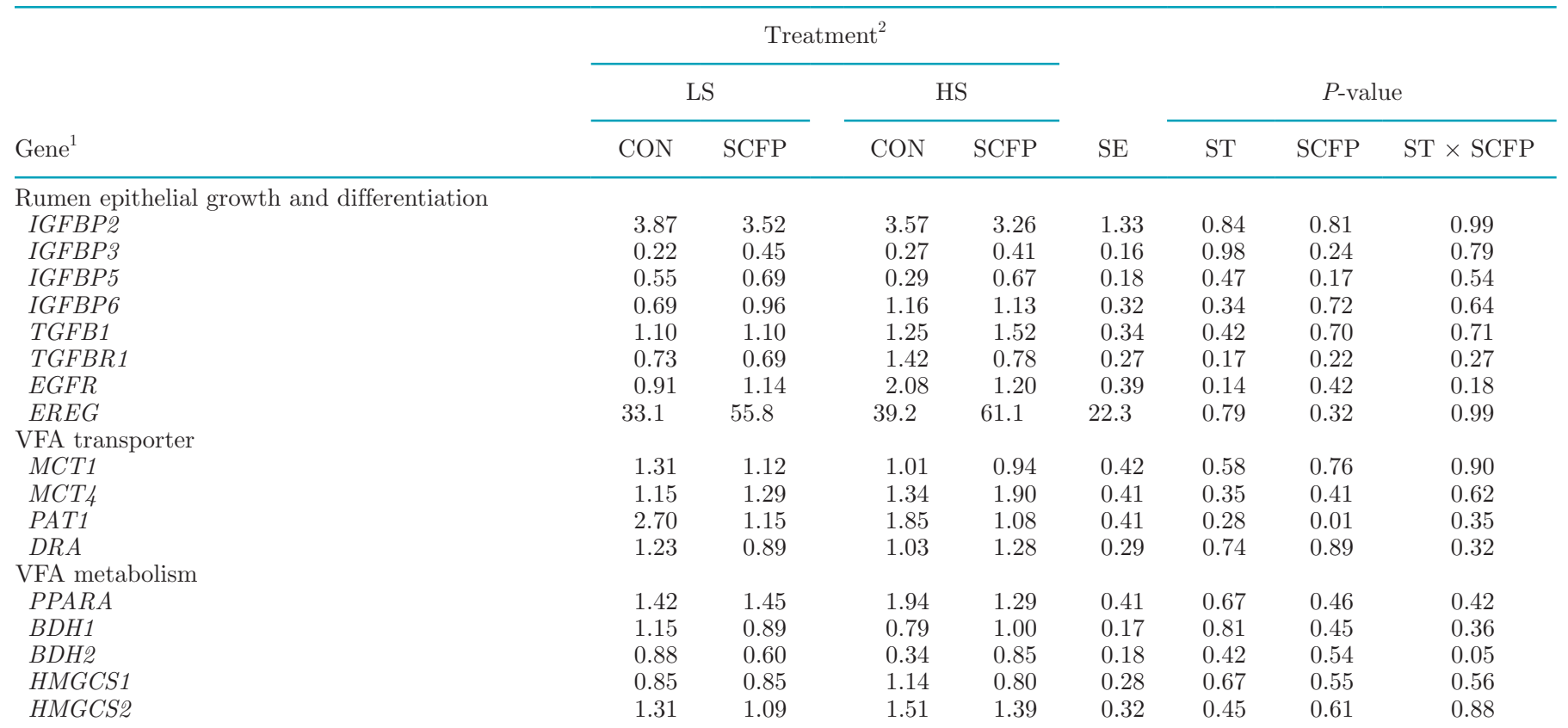

${ }^{1} I G F B P 2=$ IGF-binding protein 2; IGFBP3 = IGF-binding protein 3; IGFBP5 = IGF-binding protein 5; IGFBP6 = IGF-binding protein 6 ; $T G F B 1=$ transforming growth factor $\beta 1 ; T G F B R 1=$ transforming growth factor $\beta$ receptor $1 ; E G F R=$ epidermal growth factor receptor; $E R E G=$ epiregulin; $M C T 1=$ monocarboxylate cotransporter, isoform $1 ; M C T 4=$ monocarboxylate cotransporter, isoform $4 ;$ PAT1 $=$ putative anion transporter, isoform $1 ; D R A=$ downregulated in adenoma; $P P A R A=$ peroxisome proliferator-activated receptor- $\alpha ; B D H 1=\beta-118$ hydroxybutyrate dehydrogenase, isoform $1 ; B D H 2=\beta$-118 hydroxybutyrate dehydrogenase, isoform $2 ; H M G C S 1=3$-hydroxy-3-methylglutarylCoA synthase 1; HMGCS2 = 3-hydroxy-3-methylglutaryl-CoA synthase 2.

${ }^{2} \mathrm{LS}=$ low-starch fresh diets; HS = high-starch fresh diets; CON = control diet with no SCFP supplementation; SCFP $=$ diet with SCFP supplementation. 
dition, $\beta$-glucan and mannan oligosaccharides, as the main cell wall components of Saccharomyces cerevisiae, may increase rumen epithelium health by preventing the colonization of pathogens (Heinrichs et al., 2003; Ruiz-Herrera, 2016). Supplementing SCFP to lactating cows reduced plasma concentration of LPS (Zhang et al., 2013). Therefore, it is possible that SCFP cows had less rumen epithelial damage compared with CON cows, contributing to greater VFA absorption and less VFA accumulation in the rumen.

\section{Effects of Starch Content During the Fresh Period}

In our companion papers, we found that feeding LS diets during the fresh period increased milk production without affecting DMI (Shi et al., 2019) and reduced immune activation in rumen tissue at d 21 after calving as indicated by lower mRNA abundance of IL receptor associated kinase- 1 in LS cows compared with HS cows (Knoblock et al., 2019).

In several studies, the rapid change from a highforage diet to a high-grain diet decreased rumen $\mathrm{pH}$ and induced SARA in Holstein dairy cows immediately after switching the diet (Steele et al., 2011; Li et al., 2012; AlZahal et al., 2014). Therefore, it was expected that the change from a controlled-energy close-up diet (25.6\% NFC) with $29 \%$ inclusion of straw (DM basis) to fresh diets that contained a large amount of grain (41.1\% NFC) would largely reduce rumen $\mathrm{pH}$ immediately after parturition. In our study, rumen $\mathrm{pH}$ decreased and the duration and area of rumen $\mathrm{pH}$ below 5.8 increased by approximately 24-fold and 27-fold, respectively, immediately after calving as observed during the $\mathrm{d} 1$ sampling period compared with the $\mathrm{d}-3$ sampling period. Similar changes in rumen $\mathrm{pH}$ around parturition have been reported by Penner et al. (2007), in which rumen $\mathrm{pH}$ decreased substantially immediately after calving during d 1 to 5 .

As rumen $\mathrm{pH}$ decreases with excessive amounts of NFC, we hypothesized that feeding an LS diet during the fresh period would reduce the decrease in rumen $\mathrm{pH}$ compared with feeding an HS diet. As expected, feeding LS diets tended to increase nadir ruminal $\mathrm{pH}$ compared with feeding HS diets during the d 1 sampling period. Although duration and area of $\mathrm{pH}$ below 5.8 were not different between the LS and HS groups, high variation existed among animals as indicated by the high standard error. The substantial variation accounted for approximately 44 and $66 \%$ of the mean for duration and area of $\mathrm{pH}$ below 5.8, respectively, which probably masked any treatment differences (Penner et al., 2007). The increase in rumen $\mathrm{pH}$ associated with feeding an LS diet was also observed in other studies for dairy cows after peak lactation, such as a tendency of higher nadir rumen pH (Zhang et al., 2010) and a tendency of reduced pH range (Voelker and Allen, 2003). However, dietary starch content had no effect on rumen $\mathrm{pH}$ during both the $\mathrm{d} 7$ and 21 sampling periods. In contrast to our results, Rabelo et al. (2003) reported that the cows fed a high-NFC diet $(47.2 \%$ NFC) during the fresh period had lower ruminal $\mathrm{pH}$ compared with those fed a low-NFC diet (41.1\% NFC) by the end of the fresh period $(17 \pm 2.0 \mathrm{~d})$. The decreased rumen $\mathrm{pH}$ in their study may be a result of a tendency for greater DMI for the cows fed a high-NFC diet compared with those fed a low-NFC diet during the fresh period (d 1 to 20 ), whereas DMI was not affected by starch content in our study. In addition, rumen fluid samples were taken only once in the study of Rabelo et al. (2003) at 5 to $6 \mathrm{~h}$ after feeding for $\mathrm{pH}$ measurement; therefore, the rumen $\mathrm{pH}$ data in their study were not fully representative of the changes in rumen fermentation.

We speculated that the lack of difference in rumen $\mathrm{pH}$ in response to different dietary starch content during the $\mathrm{d} 7$ and 21 sampling periods may be associated with the rapid adaptation of the rumen epithelium in dairy cows fed the HS diets, which allows a faster absorption of VFA from the rumen. The absorption rate of VFA has been shown to be affected by rumen papillae surface area (Melo et al., 2013), and VFA are commonly considered the stimulatory factor of the proliferation of the rumen epithelium (Bannink et al., 2012). Studies have reported that increasing the energy intake of dairy cows increased the absorptive surface of rumen epithelium (Melo et al., 2013). More recently, Dieho et al. (2016) found that rumen papillae respond to a rapid increase in concentrate allowance after calving by increasing growth rate, resulting in increased rumen papillae surface area. Similar to our results, total VFA concentration and rumen $\mathrm{pH}$ were not affected by the rate of increase in concentrate allowance in the study by Dieho et al. (2016). Therefore, it is likely that the cows fed HS diets in our study had greater rumen epithelial surface area compared with those fed LS diets, contributing to higher VFA absorption in HS cows and preventing the decrease in rumen $\mathrm{pH}$ from additional starch fermentation. In addition, DMI of cows during the fresh period was relatively low; therefore, the difference in starch intake between LS and HS cows might not be large enough to affect rumen $\mathrm{pH}$, and HS cows may have been able to buffer the extra acid load. Furthermore, the high variation within individual treatments as mentioned previously may also contribute to the lack of response during the $\mathrm{d} 7$ and 21 sampling periods.

In addition to the rumen $\mathrm{pH}$ during the $\mathrm{d} 21$ sampling period, the expression of genes encoding for rumen epithelial growth, VFA transporters, and VFA metabolism 
was not affected by dietary starch content. We noticed that in studies where differential expression of genes involved in the IGF axis (Steele et al., 2011, 2012) and VFA absorption (Yan et al., 2014) were observed, there were larger differences in dietary starch or NFC content. The difference in dietary starch content between the high-forage and high-grain diets was 34 percentage units (DM basis) in Steele et al. (2011) and 11 percentage units (DM basis) in Steele et al. (2012). In addition, the difference in dietary NFC content was 16 percentage units in the study of Yan et al. (2014). However, the difference in starch content between LS and HS diets in our study was approximately 6 percentage units, which was lower than in those studies mentioned above. Therefore, the lack of response in expression of genes evaluated in our study may be partially attributed to the relatively lower difference in dietary starch content.

\section{CONCLUSIONS}

The sudden change in diet composition around calving decreases rumen $\mathrm{pH}$ immediately after calving. Supplementation of SCFP during the calving transition may reduce the range of rumen $\mathrm{pH}$ after calving and the duration of SARA by the end of the calving transition, and feeding a low-starch diet during the fresh period may help increase rumen $\mathrm{pH}$ immediately after parturition.

\section{ACKNOWLEDGMENTS}

The authors gratefully acknowledge financial support by Alberta Milk (Edmonton, AB, Canada), Diamond V Inc. (Cedar Rapids, IA), and the Natural Sciences and Engineering Research Council of Canada (Ottawa, ON, Canada).

\section{REFERENCES}

Albornoz, R. I., and M. S. Allen. 2018. Highly fermentable starch at different diet starch concentrations decreased feed intake and milk yield of cows in the early postpartum period. J. Dairy Sci. 101:8902-8915.

AlZahal, O., L. Dionissopoulos, A. H. Laarman, N. Walker, and B. W. McBride. 2014. Active dry Saccharomyces cerevisiae can alleviate the effects of subacute ruminal acidosis in lactating dairy cows. J. Dairy Sci. 97:7751-7763.

Arakaki, L. C., R. C. Stahringer, J. E. Garrett, and B. A. Dehority. 2000. The effects of feeding monensin and yeast culture, alone or in combination, on the concentration and generic composition of rumen protozoa in steers fed on low-quality pasture supplemented with increasing levels of concentrate. Anim. Feed Sci. Technol. $84: 121-127$.

Bach, L. A. 2016. Current ideas on the biology of IFGBP-6: More than an IGF-II inhibitor? Growth Horm. IGF Res. 30-31:81-86.

Bannink, A., W. J. J. Gerrits, J. France, and J. Dijkstra. 2012. Variation in rumen fermentation and the rumen wall during the transition period in dairy cows. Anim. Feed Sci. Technol. 172:80-94.
Callaway, E. S., and S. A. Martin. 1997. Effects of a Saccharomyces cerevisiae culture on ruminal bacteria that utilize lactate and digest cellulose. J. Dairy Sci. 80:2035-2044.

Canadian Council on Animal Care. 2009. Guidelines on the Care and Use of Farm Animals in Research, Teaching and Testing. Canadian Council on Animal Care, Ottawa, ON, Canada.

Chomczynski, P., and N. Sacchi. 1987. Single-step method of RNA isolation by acid quanidinium thiocynate phenol chloroform extraction. Anal. Biochem. 162:156-159.

Connor, E. E., R. W. Li, R. L. Baldwin, and C. Li. 2010. Gene expression in the digestive tissues of ruminants and their relationships with feeding and digestive processes. Animal 4:993-1007.

Dias, A. L. G., J. A. Freitas, B. Micai, R. A. Azevedo, L. F. Greco, and J. E. P. Santos. 2018. Effect of supplemental yeast culture and dietary starch content on rumen fermentation and digestion in dairy cows. J. Dairy Sci. 101:201-221.

Dieho, K., A. Bannink, I. A. L. Geurts, J. T. Schonewille, G. Gort, and J. Dijkstra. 2016. Morphological adaptation of rumen papillae during the dry period and early lactation as affected by rate of increase of concentrate allowance. J. Dairy Sci. 99:2339-2352.

Dieho, K., J. van Baal, L. Kruijt, A. Bannink, J. T. Schonewille, D. Carreño, W. H. Hendriks, and J. Dijkstra. 2017. Effect of supplemental concentrate during the dry period or early lactation on rumen epithelium gene and protein expression in dairy cattle during the transition period. J. Dairy Sci. 100:7227-7245.

Erasmus, L. J., P. H. Robinson, A. Ahmadi, R. Hinders, and J. E. Garrett. 2005. Influence of prepartum and postpartum supplementation of a yeast culture and monensin, or both, on ruminal fermentation and performance of multiparous dairy cows. Anim. Feed Sci. Technol. 122:219-239.

Esposito, G., P. C. Irons, E. C. Webb, and A. Chapwanya. 2014. Interactions between negative energy balance, metabolic disease, uterine health and immune response in transition dairy cows. Anim. Reprod. Sci. 144:60-71.

Guo, J., Z. Zhang, H. Derakhshani, I. Yoon, J. C. Plaizier, and E. Khafipour. 2018. Effect of subacute ruminal acidosis (SARA) and Saccharomyces cerevisiae fermentation products on gastrointestinal microbiome of dairy cows. J. Anim. Sci. 96:398 (Abstr.).

Harrison, G. A., R. W. Hemken, K. A. Dawson, R. J. Harmon, and K. B. Barker. 1988. Influence of addition of yeast culture supplement to diets of lactating cows on ruminal fermentation and microbial populations. J. Dairy Sci. 71:2967-2975.

Heinrichs, A. J., C. M. Jones, and B. S. Heinrichs. 2003. Effects of mannan oligosaccharide or antibiotics in neonatal diets on health and growth of dairy calves. J. Dairy Sci. 86:4064-4069.

Hristov, A. N., G. Varga, T. Cassidy, M. Long, K. Heyler, S. K. R. Karnati, B. Corl, C. J. Hovde, and I. Yoon. 2010. Effect of Saccharomyces cerevisiae fermentation product on ruminal fermentation and nutrient utilization in dairy cows. J. Dairy Sci. 93:682-692.

Khorasani, G. R., E. K. Okine, and J. J. Kennelly. 1996. Forage source alters nutrient supply to the intestine without influencing milk yield. J. Dairy Sci. 79:862-872.

Knoblock, C. E., W. Shi, I. Yoon, and M. Oba. 2019. Effects of supplementing a Saccharomyces cerevisiae fermentation product during the periparturient period on the immune response of dairy cows fed fresh diets differing in starch content. J. Dairy Sci. 102:6199-6209.

Krause, K. M., and G. R. Oetzel. 2006. Understanding and preventing subacute ruminal acidosis in dairy herds: A review. Anim. Feed Sci. Technol. 126:215-236.

Li, S., E. Khafipour, D. O. Krause, A. Kroeker, J. C. RodrguezLecompte, G. N. Gozho, and J. C. Plaizier. 2012. Effects of subacute ruminal acidosis challenges on fermentation and endotoxins in the rumen and hindgut of dairy cows. J. Dairy Sci. 95:294-303.

Livak, K. J., and T. D. Schmittgen. 2001. Analysis of relative gene expression data using real-time quantitative PCR and the $2^{-\triangle \Delta \mathrm{CT}}$ method. Methods 25:402-408.

Ma, L., M. Zhao, L. Zhao, J. Xu, J. J. Loor, and D. Bu. 2017. Effects of dietary neutral detergent fiber and starch ratio on rumen epithelial cell morphological structure and gene expression in dairy cows. J. Dairy Sci. 100:3705-3712. 
Malmuthuge, N., M. Li, L. A. Goonewardene, M. Oba, and L. L. Guan. 2013. Effect of calf starter feeding on gut microbial diversity and expression of genes involved in host immune responses and tight junctions in dairy calves during weaning transition. J. Dairy Sci. 96:3189-3200

Mao, H. L., H. Mao, J. Wang, J. Liu, and I. Yoon. 2013. Effects of Saccharomyces cerevisiae fermentation product on in vitro fermentation and microbial communities of low-quality forages and mixed diets. J. Anim. Sci. 91:3291-3298.

Melo, L. Q., S. F. Costa, F. Lopes, M. C. Guerreiro, L. E. Armentano, and M. N. Pereira. 2013. Rumen morphometrics and the effect of digesta $\mathrm{pH}$ and volume on volatile fatty acid absorption. J. Anim. Sci. 91:1775-1783.

Minuti, A., A. Palladino, M. J. Khan, S. Alqarni, A. Agrawal, F. Piccioli-Capelli, F. Hidalgo, F. C. Cardoso, E. Trevisi, and J. J. Loor. 2015. Abundance of ruminal bacteria, epithelial gene expression, and systemic biomarkers of metabolism and inflammation are altered during the peripartal period in dairy cows. J. Dairy Sci. 98:8940-8951.

NRC. 2001. Nutrient Requirements for Dairy Cattle. 7th rev. ed. National Academy Press, Washington, DC.

Penner, G. B., K. A. Beauchemin, and T. Mutsvangwa. 2006. An evaluation of the accuracy and precision of a stand-alone submersible continuous ruminal $\mathrm{pH}$ measurement system. J. Dairy Sci. 89:2132-2140.

Penner, G. B., K. A. Beauchemin, and T. Mutsvangwa. 2007. Severity of ruminal acidosis in primiparous Holstein cows during the periparturient period. J. Dairy Sci. 90:365-375.

Rabelo, E., R. L. Rezende, S. J. Bertics, and R. R. Grummer. 2003. Effects of transition diets varying in dietary energy density on lactation performance and ruminal parameters of dairy cows. J. Dairy Sci. 86:916-925.

Rhoads, M. L., J. P. Meyer, W. R. Lamberson, D. H. Keisler, and M. C. Lucy. 2008. Uterine and hepatic gene expression in relation to days postpartum, estrus, and pregnancy in postpartum dairy cows. J. Dairy Sci. 91:140-150.

Robinson, T. L., I. A. Sutherland, and J. Sutherland. 2007. Validation of candidate bovine reference genes for use with real-time PCR. Vet. Immunol. Immunopathol. 115:160-165.

Ruiz-Herrera, J. 2016. Fungal Cell Wall: Structure, Synthesis, and Assembly. CRC Press, Boca Raton, FL.

Shen, Y., H. Wang, T. Ran, I. Yoon, A. M. Saleem, and W. Yang. 2018. Influence of yeast culture and feed antibiotics on ruminal fermentation and site and extent of digestion in beef heifers fed high grain rations. J. Anim. Sci. 96:3916-3927.
Shi, W., C. E. Knoblock, K. V. Murphy, T. C. Bruinjé, I. Yoon, D. J. Ambrose, and M. Oba. 2019. Effects of supplementing a Saccharomyces cerevisiae fermentation product during the periparturient period on performance of dairy cows fed fresh diets differing in starch content. J. Dairy Sci. 102:3082-3096.

Steele, M. A., O. AlZahal, M. E. Walpole, and B. W. McBride. 2012 Short communication: Grain-induced subacute ruminal acidosis is associated with the differential expression of insulin-like growth factor-binding proteins in rumen papillae of lactating dairy cattle. J. Dairy Sci. 95:6072-6076.

Steele, M. A., J. Croom, M. Kahler, O. AlZahal, S. E. Hook, K. Plaizier, and B. W. McBride. 2011. Bovine rumen epithelium undergoes rapid structural adaptations during grain-induced subacute ruminal acidosis. Am. J. Physiol. Regul. Integr. Comp. Physiol 300:R1515-R1523.

Steele, M. A., C. Schiestel, O. AlZahal, L. Dionissopoulos, A. H. Laarman, J. C. Matthews, and B. W. McBride. 2015. The periparturient period is associated with structural and transcriptomic adaptations of rumen papillae in dairy cattle. J. Dairy Sci. 98:2583-2595.

Stone, W. C. 2004. Nutritional approaches to minimize subacute ruminal acidosis and laminitis in dairy cattle. J. Dairy Sci. 87:E13-E26.

Voelker, J. A., and M. S. Allen. 2003. Pelleted beet pulp substituted for high-moisture corn: 3. Effects on ruminal fermentation, $\mathrm{pH}$, and microbial protein efficiency in lactating dairy cows. J. Dairy Sci. 86:3562-3570.

Williams, A. G., and G. S. Coleman. 1997. The rumen protozoa. Pages 73-139 in The Rumen Microbial Ecosystem. 2nd ed. P. N. Hobson and C. S. Stewart, ed. Chapman \& Hall, London, UK.

Yan, L., B. Zhang, and Z. Shen. 2014. Dietary modulation of the expression of genes involved in short-chain fatty acid absorption in the rumen epithelium is related to short-chain fatty acid concentration and $\mathrm{pH}$ in the rumen of goats. J. Dairy Sci. 97:5668-5675.

Zhang, R. Y., I. Yoon, W. Y. Zhu, and S. Y. Mao. 2013. Effect of Saccharomyces cerevisiae fermentation product on lactation performance and lipopolysaccharide concentration of dairy cows. Asianaustralas. J. Anim. Sci. 26:1137-1143.

Zhang, S. Z., G. B. Penner, W. Z. Yang, and M. Oba. 2010. Effects of partially replacing barley silage or barley grain with dried distillers grains with solubles on rumen fermentation and milk production of lactating dairy cows. J. Dairy Sci. 93:3231-3242.

Zhu, W., Z. Wei, N. Xu, F. Yang, I. Yoon, Y. Chung, J. Liu, and J. Wang. 2017. Effects of Saccharomyces cerevisiae fermentation products on performance and rumen fermentation and microbiota in dairy cows fed a diet containing low quality forage. J. Anim. Sci. Biotechnol. 8:36. 